ASSOCIAÇÃO

NACIO
DE

PÓS-GRAD

EPESQUISA

EMADMINISTRAÇÃO

\title{
Stewardship-oriented Culture and Family Firm Performance: A Study on the Moderating Effects in an Emerging Economy
}

\author{
Daniel Magalhães Mucci ${ }^{1}$ \\ Fábio Frezatti ${ }^{1}$ \\ Ann Jorissen ${ }^{2}$ \\ Diógenes de Souza Bido ${ }^{3}$ \\ ${ }^{1}$ Universidade de São Paulo, São Paulo, SP, Brazil \\ ${ }^{2}$ Universiteit Antwerpen, Antwerpen, Belgium \\ ${ }^{3}$ Universidade Presbiteriana Mackenzie, São Paulo, SP, Brazil
}

Received 25 November 2018. This paper was with the authors for three revisions. Accepted 3 April 2020. First published online 5 May 2020.

João Mauricio Gama Boaventura was the associate editor for this article.

Editor-in-chief: Carlo Gabriel Porto Bellini

Editorial assistant: Luciane Kato Kiwara 


\begin{abstract}
Prior literature has provided inconclusive evidence on the effects of family involvement in management (FIM) on family business (FB) performance. However, so far in the literature, there have been very few attempts to investigate FIM and family essence simultaneously as antecedents of FB performance. Therefore, we address this gap by studying how a stewardship-oriented culture (being a feature of FB essence) moderates the relationship between FIM and FB performance. We test our hypotheses with the Structural Equation Modeling technique using survey data in combination with archival data on a sample of 69 medium and large private Brazilian FBs. We find that a stewardship-oriented culture makes the relationship between a family CEO and FB performance weaker and observe that a stewardship has no moderating effect on the relationship between FIM and FB performance. These findings contradict prior literature on the beneficial role of stewardship in family-managed FB. Only in case of a nonfamily CEO, a stewardshiporiented culture positively moderates the relationship with FB performance. In addition, our study reveals a U-shaped nonlinear relationship between the level of FIM and FB performance, which is consistent with recent literature on the existence of faultlines derived from heterogeneous TMT and the impact on firm outcome.
\end{abstract}

Keywords: stewardship theory; performance; family firm; family involvement in management; family CEO.

JEL code: M1, M100 


\section{Introduction}

A lot of research on the effect of family involvement over family business (FB) performance can be found in the literature (e.g., Basco, 2013; González-Cruz \& Cruz-Ros, 2016; Wagner, Block, Miller, Schwens, \& Xi, 2015). Favorable and unfavorable perspectives based on different theoretical frameworks such as agency theory, stewardship theory, faultlines, the resource-based view, and socioemotional wealth are used in the literature to discuss this relationship (e.g., Basco, Campopiano, Calabrò, \& Kraus, 2019; Chirico \& Bau', 2014; Kim \& Gao, 2013). This literature has mainly focused on the comparison between family and nonfamily firm performance (Rutherford, Kuratko, \& Holt, 2008) and, more recently, some studies have focused exclusively on FBs, addressing FB heterogeneity (Nordqvist, Sharma, \& Chirico, 2014) based on different levels of family involvement (Basco, 2013; Basco et al., 2019; González-Cruz \& Cruz-Ros, 2016).

Despite the existence of a whole stream of literature on FB performance, the empirical evidence is still inconclusive (Garcia-Castro \& Aguilera, 2014; González-Cruz \& Cruz-Ros, 2016). There are some attempts in recent studies to provide a more compelling direction regarding the antecedents of FB performance in multiple contexts (Wagner et al., 2015). Most studies in the literature have looked at ability variables (such as family involvement in management and ownership) and there have been few attempts to investigate these elements together with family essence (such as orientation or cultural aspects), which might simultaneously capture FB particularities and their effects on performance (Basco, 2013; Basco \& Voordeckers, 2015; De Massis, Kotlar, Chua, \& Chrisman, 2014). According to Basco (2013), the essence approach follows the behavioral perspective (Chrisman, Chua, \& Sharma, 2005) and the resource-based view (Habbershon \& Williams, 1999) and intends to depict what happens inside the firm while the ability captures the potential family influence in the FB. In fact, researchers have proposed that the association between family involvement in management (FIM) and FB performance might be moderated by family-longevity goals (Kim \& Gao, 2013), identity (Calabró, Campopiano, \& Basco, 2017), and listed versus unlisted status (Minichilli, Corbetta, \& MacMillan, 2010; O’Boyle, Pollack, \& Rutherford, 2012). Other studies have looked at mediators, such as a long-term orientation among management (Hoffmann, Wulf, \& Stubner, 2016) and objective achievement perceptions (Basco et al., 2019). Drawing attention to the importance of considering both ability and family essence variables, Wagner, Block, Miller, Schwens and $\mathrm{Xi}$ (2015) suggest that individualistic versus collectivist settings might help to explain the conflicting evidence from prior literature regarding FB performance. Hence, we address this gap in the literature regarding the circumstances that might enhance or damage the FIM-performance relationship, particularly concerning cultural aspects encompassed by the stewardship-oriented culture (e.g., Zahra, Hayton, Neubaum, Dibrell, \& Craig, 2008). Stewardship-oriented culture has been defined as "a collective, supportive, and caring environment" (Zahra et al., 2008, p. 1043) which relates to a collectivist setting (Wagner et al., 2015) and to a long-term orientation (Kim \& Gao, 2013). Prior literature indicates that a stewardship-oriented culture (Zahra et al., 2008) can be seen as a component of the level of familiness in a FB since it is expected to enhance the bright side of the presence of family members in the top management team (Kim \& Gao, 2013; Miller \& Le Breton-Miller, 2006).

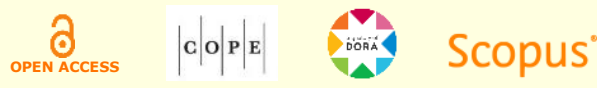


Considering that a stewardship-oriented culture might assist a FB in enhancing the bright side of family influence (e.g., Habbershon \& Williams, 1999) and suppressing particular family agency problems resulting from the dark side of family influence on the business (e.g., Lubatkin, Schulze, Ling, \& Dino, 2005), we propose the following research question: Does a stewardship-oriented culture favorably moderate the association between the level of family involvement in management and the family firm's financial performance? We discuss the association between family involvement in management and FB financial performance and investigate whether a stewardship-oriented culture plays a moderating role in this relationship. We focus on family involvement in management, particularly the Top Management Team (TMT), since these top executives have a relevant influence on the firm's performance. The Chief Executive Officer (CEO) might also play a role due to his/her strategic leadership in the top team (D'Allura, 2019). In terms of the essence of FBs, we focus on the stewardship-oriented culture, which might moderate the FIM-performance relationship.

First, this study contributes to prior literature by addressing the claim that familiness cannot be solely captured by the level of family involvement in the business (Irava \& Moores, 2010; Pearson, Carr, \& Shaw, 2008). This topic is relevant since the prevalent reasoning of most studies is that the level of family involvement in the group of top executives reflects the level of familiness of the FB (Minichilli et al., 2010). Hence, this study addresses the need to investigate ability and family essence variables simultaneously to explain the association between FIM and FB performance (Basco, 2013; Basco \& Voordeckers, 2015). We focus on the presence of a stewardship-oriented culture in the FB, bringing more evidence to the family business literature on existing possible moderators on the relationship between FIM and FB performance. Prior literature has focused on family goals, family identity, firm listing status as possible moderators (e.g., Calabró et al., 2017; Kim \& Gao, 2013). Stewardship theory can shed additional light on the understanding of how family involvement in management is related to FB performance, particularly focusing on the agency-suppressing and stewardship-enhancing roles of a stewardshiporiented culture, as a moderator variable. The focus on stewardship as a cultural dimension might provide additional evidence to prior literature that has used mainly a behavioral agency lens (e.g., Basco, 2013; Basco et al., 2019). Our study also considers two different aspects of family involvement in the management of a FB, namely whether a family $\mathrm{CEO}$ is present and the ratio of family managers present in the family firm's Top Management Team (TMT). Most of the prior literature on family firm performance has focused exclusively on the ratio of family involvement in the board or management, but not on family CEOs, especially when considering moderating effects on this relationship (e.g., Kim \& Gao, 2013).

In addition, despite an extensive screening of multiple databases to identify papers that have discussed the antecedents of FB performance, there is little evidence regarding Brazilian FBs (Beuren, Politelo, \& Martins, 2016; Brandt, Kroenke, \& Pletsch, 2018; Wagner et al., 2015). For instance, Brazilian FBs have a higher sense of tradition and heritage than Anglo-Saxon FBs (Frezatti, Bido, Mucci, \& Beck, 2017; Gupta \& Levenburg, 2010) and face particular governance challenges that might affect their performance (Instituto Brasileiro de Governança Corporativa [IBGC], 2019). Hofstede (2001) indicates that Brazilian culture presents a higher level of power distance, collectivism, and risk avoidance than developed economies such as those in the US and

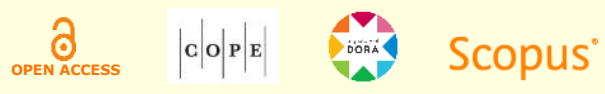


Germany, which might have implications for the role that family and nonfamily managers play in influencing FB performance. Prior studies developed in Brazil have focused on the ownershipperformance relationship by comparing FBs to nonfamily businesses (NFBs) (Beuren et al., 2016; Peixoto \& Buccini, 2013), while there is little evidence on FIM. Finally, in the international literature, most studies concentrate on small and medium enterprises (SMEs) or on publicly listed firms (e.g., Basco, 2013) from the US and Europe, while there is little attention paid to how FIM affects performance, especially in private FBs, such as those featured in this study. Medium and large private FBs might encompass a higher level of tradition, age, and involvement of different generations of the family in the firm, which might result in different interpretations of the findings of prior studies.

This paper is organized into five sections, including this introduction. In second section, we present the literature and the conceptual model and research hypotheses. In third section, we show the methodology, and in fourth section, we explore the results of the Structural Equation Modeling analysis. Finally, we present the discussions and conclusions and highlight the limitations of this study.

\section{Literature Review and Hypotheses}

There is a vast stream of research that has investigated the effects of family involvement in management on FB performance (Rutherford et al., 2008; Wagner et al., 2015). Basically, there are two opposing views on the family's influence on firm performance, depending on whether family involvement is considered an advantage (the bright side of family influence) or a disadvantage (the dark side of family influence) to the firm (Chirico \& Bau', 2014; Miller \& Le Breton-Miller, 2006; Rutherford et al., 2008). The literature has mainly focused on comparing FBs and NFBs. More recently, there has been emerging literature focusing on the heterogeneity among FBs (e.g., Basco, 2013; Basco et al., 2019; Kim \& Gao, 2013) with respect to family involvement (for instance, in ownership, management, and generations) (Chrisman et al., 2012) and family essence characteristics and behaviors (e.g., long-term orientation and stewardship).

The overall model discussed later in this section includes three hypotheses regarding the direct effects, which are grounded in the prior literature concerning the consequences of family involvement in management, and two moderator hypotheses, which are based on the stewardship theoretical background. Family involvement in management is divided into two components: the family affiliation of the CEO and the ratio of family managers in the TMT (Ensley \& Pearson, 2005; Minichilli et al., 2010). In the next subsections, we present the underlying rationale for the hypotheses of this study.

\section{The relationship between the presence of a family CEO and firm performance}

Chief Executive Officers (CEOs) are leaders of the Top Management Team and are considered the most powerful actors in the organization (Finkelstein \& Hambrick, 1996; Finkelstein, Hambrick, \& Cannella, 2008). They have the most significant power to influence the FB's

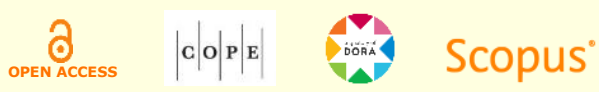


performance because they dominate all the firm's decision-making processes, such as the delegation of responsibilities in the firm's governance structure (González-Cruz \& Cruz-Ros, 2016; Minichilli et al., 2010).

Prior literature has suggested that a family CEO might behave altruistically in a firm (Chrisman et al., 2005; Schulze, Lubatkin, \& Dino, 2003) and might also have a long-term view of the decision-making process (Miller \& Le Breton-Miller, 2006). A family CEO is expected to behave as a steward in the firm, presenting a high level of loyalty, commitment, and identification (Davis, Allen, \& Hayes, 2010; Henssen, Voordeckers, Lambrechts, \& Koiranen, 2014), which has been conceptualized as the bright side of family involvement (e.g., Minichili et al., 2010).

In addition, family CEOs usually have lengthy job tenures and long-term investment horizons, and these characteristics have been associated with superior performance (Miller \& Le BretonMiller, 2006). Finally, a FB that has a family CEO would have reduced traditional agency costs for aligning managers' and principals' goals in the firm (Jensen \& Meckling, 1976; Madison, Holt, Kellermanns, \& Ranft, 2016), which is also expected to enhance FB performance. Based on the previous literature (Anderson \& Reeb, 2003; González-Cruz \& Cruz-Ros, 2016; Minichilli et al., 2010; Villalonga \& Amit, 2006), we hypothesize that:

H1: There is a positive association between the presence of a family CEO and the family firm's financial performance.

\section{The relationship between the ratio of family managers in the TMT and firm performance}

The previous empirical literature has suggested that family involvement in management, in terms of the ratio of family managers present in the Top Management Team, is positively associated with FB performance (Rutherford et al., 2008; Sciascia, Mazzola, \& Chirico, 2013). These studies indicate that the benefits of a high level for the ratio of family managers in the TMT consist of reduced agency problems, lower agency costs, and reduced information asymmetry (Chrisman, Chua, \& Litz, 2004; Miller \& Le Breton-Miller, 2006).

With respect to manager behavior, family managers are expected to behave as stewards, generating an individual sense of identification, loyalty, commitment, and trust, among other proorganizational attitudes and behaviors (Davis et al., 2010; Davis, Schoorman, \& Donaldson, 1997; Neubaum, Thomas, Dibrell, \& Craig, 2017) expected to be positively related to higher FB financial performance. Family managers, as stewards, might have an intrinsic motivation to serve the principals' interests and, consequently, the firm's goals (Davis et al., 1997; Davis et al., 2010). Therefore, we hypothesize that:

$\mathrm{H} 2 \mathrm{a}$ : There is a positive association between the ratio of family managers in the TMT and the family firm's financial performance.

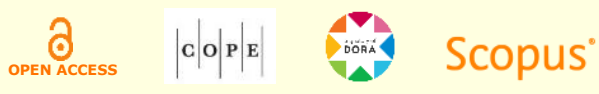


Recent studies have presented conflicting evidence regarding the linear association between family involvement in management, in terms of the presence of family managers in the TMT, and performance (Garcia-Castro \& Aguilera, 2014; González-Cruz \& Cruz-Ros, 2016). These conflicting findings have motivated researchers to discuss nonlinear relationships among the ratios of family managers both on the board of directors and in the TMT and firm performance (Basco et al., 2019; De Massis, Kotlar, Campopiano, \& Cassia, 2015; González-Cruz \& Cruz-Ros, 2016; Mazzola, Sciascia, \& Kellermanns, 2013; Minichilli et al., 2010).

These studies reveal that the benefits of having family managers in the TMT in terms of the firm's performance are significant only if their involvement is of a certain level (Sciascia \& Mazzola, 2008). However, when this involvement reaches a higher degree, the FB faces typical family agency costs (Madison et al., 2016; Villalonga \& Amit, 2006) such as nepotism (Jaskiewicz, Uhlenbruck, Balkin, \& Reay, 2013) and entrenchment (Chrisman et al., 2005). We argue that at extreme levels of family involvement in the TMT, the within-family agency costs resulting from family managers' conflicts and emotional involvement with the firm exceed the benefits of reduced traditional principal-agent costs (Chirico \& Bau', 2014; Chrisman et al., 2004; Lubatkin et al., 2005).

Moreover, a high level of family managers in the TMT leads to a lower diversity of professional skills or a lack of expertise in them (González, Gúzmán, Pablo, \& Trujillo, 2020; Patel \& Cooper, 2014; Vandekerkhof, Steijvers, Hendriks, \& Voordeckers, 2015), which might negatively influence the firm's performance. The presence of nonfamily managers could bring diverse perceptions and expertise to the TMT that are complementary to those of family managers. The presence of nonfamily managers in the TMT might improve the FB's decision-making processes (Chrisman, Memili, \& Misra, 2014; De Massis et al., 2015; Vandekerkhof et al., 2015), such as formal strategic and financial planning (Filbeck \& Lee, 2000; Speckbacher \& Wentges, 2012). In sum, as family managers are constrained by a lack of professional competencies (Dyer, 1989), a high level of family managers in the TMT might negatively influence performance.

In addition, family managers may attribute more value to nonmonetary aspects (e.g., emotions, status) to the detriment of monetary returns, which could have an impact on the firm's financial performance. Therefore, in the case of a high ratio of family managers in the TMT, the controlling family might base decision making on the preservation of their socioemotional wealth to the detriment of financial goals (Gomez-Mejia, Cruz, Berrone, \& De Castro, 2011; Kellermanns, Eddleston, \& Zellweger, 2012).

In sum, Sciascia and Mazzola (2008) argue that:

the benefits of FIM induced by lower agency costs, the stewardship effect, and lower compensation are not so evident until a certain level of FIM is reached, while, on the other hand, the negative effects deriving from conflict between family managers, nonmonetary goal orientation, reduced professional competencies, and less social capital are more likely to manifest themselves once the FIM percentage approaches 100 (p. 337).

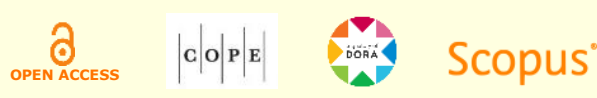


Complementarily, González-Cruz and Cruz-Ros (2016) propose that "an equal mix of family and nonfamily managers brings all the benefits of low agency costs, high and healthy stewardship behavior, and managerial competences" (p. 1453). Hence, we hypothesize that:

$\mathrm{H} 2 \mathrm{~b}$ : There is an inverted-U-shaped association between the ratio of family managers in the TMT and the family firm's financial performance.

\section{Moderation by a stewardship-oriented culture}

Motivated by the controversial findings in the current literature (Anderson \& Reeb, 2003; GarciaCastro \& Aguilera, 2014; Minichilli et al., 2010; Rutherford et al., 2008), recent studies claim there is a need to extend this discussion by also looking at potential essence variables (Basco, 2013; Basco \& Voordeckers, 2015), particularly as moderators that could suppress the agency behavioral costs while enhancing the stewardship behavioral benefits (Kellermanns et al., 2012; Le Breton-Miller, Miller, \& Lester, 2011; O’Boyle et al., 2012). Considering that a collectivist setting (Wagner et al., 2015) and a long-term perspective (Kim \& Gao, 2013) towards the firm might enhance the association between family involvement and performance, we focused on a construct called stewardship-oriented culture (e.g., Zahra et al., 2008). This construct is based on the stewardship theoretical background (Davis et al., 1997). According to Zahra, Hayton, Neubaum, Dibrell and Craig (2008), stewardship-oriented culture indicates the extent to which firms have "developed a collective, supportive, and caring environment for their employees, and provided opportunities for them to reach their potential" (p. 1043).

Therefore, we follow the understanding proposed by Dibrell and Moeller (2011), who argue that a stewardship culture acts as an operant resource by enhancing trust and shared goals within an organization. Our main argument is that when a stewardship-culture is present in FBs, it might suppress family agency behaviors (such as nepotism and entrenchment). In other words, a longterm and collectivist culture might curb family self-interested behaviors that are detrimental to business continuity. Moreover, as a consequence, it may enhance the association between family involvement in the TMT and performance, which has been previously considered a proxy for the bright side of familiness (Kellermanns et al., 2012; Minichilli et al., 2010; Villalonga \& Amit, 2006).

Stewardship theory is considered relevant for understanding the performance of FBs, particularly looking at different levels of family involvement (Corbetta \& Salvato, 2004; Zahra et al., 2008). There are several arguments that consider a stewardship-oriented culture as a resource (Dibrell \& Moeller, 2011; Eddleston \& Kellermanns, 2007). According to the resource-based view, a firm's culture cannot be easily copied by the firm's competitors. Notably, a stewardship-oriented culture positively relates to the level of communication and cohesion among managers, as well as proorganizational behaviors, which all create sustainable and inimitable competitive advantage for the firm (Miller \& Le Breton-Miller, 2006; Zahra et al., 2008). 
The sources of competitive advantage of FBs arise from the differential relational advantages of family-managed firms that are related to the stewardship perspective (Dibrell \& Moeller, 2011; Eddleston \& Kellermanns, 2007; Eddleston, Kellermanns, \& Sarathy, 2007; Zahra et al., 2008). Additionally, the prevalence of altruism, collectivism, and trust in the relationships among the FB managers (Corbetta \& Salvato, 2004) can avoid self-interested behaviors and promote congruent efforts to achieve better performance in the firm. The benefits of stewardship derive from a long-term orientation, which favors patient investments (Eddleston, Kellermanns, \& Zellweger, 2012). For instance, Kim and Gao (2013) show how a firm's family-longevity goals moderate the relationship between family involvement in management and performance, which can "engender a sense of shared identity and connections among family managers and instill in them strong loyalty and commitment to, and identification with, their organizations" (p. 268).

Prior literature has also conceptualized that a stewardship-oriented culture leads to higher strategic flexibility (Zahra et al., 2008) and an entrepreneurial orientation (Eddleston et al., 2012). However, there is little support regarding how it might enhance performance. Based on the stewardship literature (Davis et al., 2010; James, Jennings, \& Jennings, 2017; Madison et al., 2016), we argue that a stewardship-oriented culture might enhance the bright side and also suppress the dark side of family involvement and its effects on performance. Therefore, the degree to which a stewardship-oriented culture exists in the firm may influence the relationship between FIM and performance.

Finally, James, Jennings and Jennings (2017) state that stewardship mechanisms "will empower pro-organizational attitudes and behaviors amongst the majority of steward-like family managers" (p. 264), while agency mechanisms will dampen their motivation. Stewardship governance is aligned with a culture that fulfills managers' needs for autonomy, belonging, and competence (James et al., 2017; Zahra et al., 2008). Particularly, we propose that a stewardship-oriented culture maximizes the benefits of the presence of a family $\mathrm{CEO}$ and a high ratio of family managers in the TMT, enhancing the positive effect of familiness on the FB's financial performance. This is aligned with Miller and Le Breton-Miller (2006), who suggest that stewardship "can engender farsighted contributions that feed distinctive capabilities and produce superior performance" ( $\mathrm{p}$. 74). Therefore, we hypothesize that:

H3: The positive association between the presence of a family CEO and the family firm's financial performance will be stronger for higher levels of stewardship-oriented culture than for lower levels of stewardship-oriented culture.

H4: The positive association between the ratio of family managers in the TMT and the family firm's financial performance will be stronger for higher levels of stewardshiporiented culture than for lower levels of stewardship-oriented culture.

We present the theoretical model and hypotheses in Figure 1.

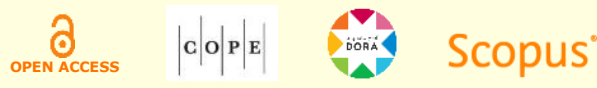




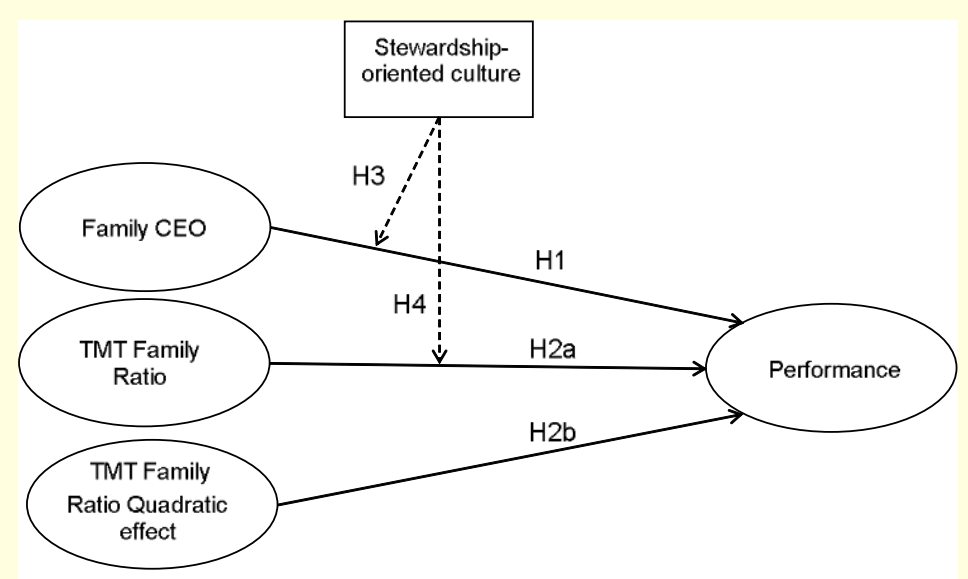

Figure 1. Theoretical model and hypotheses

\section{Methodology}

\section{Sample}

Since there is not an available dataset with Brazilian private family firms (e.g., Bressan, Schiehll, Procianoy, \& Castro, 2019), we delimit our target population based on a list of 2,953 firms collected from EMIS ${ }^{\circledR}$ database $^{1}$ in 2016 (https://www.emis.com). These firms are medium and large-sized, have limited liability or public limited legal status and are not banks, non-profit organizations, multinationals, or semi-state companies. For Brazilian Development Bank (Banco Nacional de Desenvolvimento Econômico e Social [BNDES]), medium firms have an annual operating revenue between 4.8 and 300 million BRL, while the figure for large firms is more than 300 million BRL (BNDES, n.d.).

We were able to send the invitation of the survey to most of the firms from this database and received 165 questionnaires. However, we only had available archival information on performance in 2016 for 72 of the firms that completed our survey. Thereafter, we employed an operational definition for family firms, considering that the firms in our sample had to meet at least one of the following criteria: (a) firms that have at least one family member in the top management team or (b) at least $50 \%$ of the shares have to be owned by the family (e.g., Basco, 2013; Basco et al., 2019). After applying this operational definition, we obtained a convenience sample of 69 family firms.

We combined the data collected in the questionnaire and archival information collected from the EMIS ${ }^{\circledR}$ database related to performance in 2016. By combining the survey and archival data, we mitigate the problems related to common method variance (Podsakoff, MacKenzie, \& Podsakoff, 2012). This research design, which combines two different data sources (survey and archival), has been uncommon in the FB performance literature (e.g., Basco et al., 2019).

The survey procedure follows the recommendations of the research method design established in Dillman (2007). First, as a validity procedure for the stewardship-oriented culture items (Zahra 
et al., 2008), the questionnaire was translated into Portuguese and adapted to a five-point Likert scale. Then we translated the questionnaire back into English and compared it to the original English version to check for face validity of the stewardship-oriented culture construct. Second, we applied a pre-test to nonfamily and family managers from medium and large family businesses as well as to an academic. We did not make any changes related to the measures used in this study after the pretest. After the validation of the questionnaire, we sent the first email to invite the respondents to participate, followed up by four reminders between September/2016 and February/2017.

In Table 1, we present the characteristics of the respondents of our survey. Our sample is composed of firms that have a heterogeneous distribution regarding the ratio of family managers in the TMT as well as a high percentage of family managers as the CEOs of the FBs (75.36\%). In the case of $66.67 \%$ of the respondents, the controlling family owns $100 \%$ of the firm's shares. Most of the firms in our sample have been operating for more than 51 years (75.36\%). Regarding the respondents, $49.28 \%$ report to the board of directors (Tier 1), $47.83 \%$ report to the TMT, and $2.9 \%$ report to middle managers. Our informants are mainly nonfamily managers $(81.16 \%)$ and have been working in the respective firms for more than ten years $(62.32 \%)$. Prior studies have also focused on experienced managers as informants regardless of whether they are family or nonfamily managers (e.g., Basco et al., 2019; Minichilli et al., 2010). According to the EMIS® database, $52.17 \%$ of our sample is composed of firms whose financial information was audited. Despite this limitation, we argue that this characteristic of our sample is not particularly adverse since the sample is composed of private FBs.

Table 1

\section{Sample descriptive information}

\begin{tabular}{|c|c|c|c|c|c|}
\hline & $\mathrm{n}$ & $\%$ & & $\mathrm{n}$ & $\%$ \\
\hline \multicolumn{3}{|l|}{ Panel A. Firm information } & \multicolumn{3}{|c|}{ Panel B: Respondent information } \\
\hline \multicolumn{3}{|l|}{ Panel A1: Percentage of family members in the TMT } & \multicolumn{3}{|c|}{ Panel B1: Respondent's hierarchical level } \\
\hline No family members & 14 & $20.29 \%$ & Tier 1 & 34 & $49.28 \%$ \\
\hline More than $0 \%$ and up to $25 \%$ & 15 & $21.74 \%$ & Tier 2 & 33 & $47.83 \%$ \\
\hline More than $25 \%$ and up to $50 \%$ & 20 & $28.99 \%$ & Tier 3 & 2 & $2.90 \%$ \\
\hline More than $50 \%$ but less than $100 \%$ & 9 & $13.04 \%$ & & & \\
\hline $100 \%$ & 10 & $14.49 \%$ & Panel B2: Family affiliation & & \\
\hline \multirow[t]{2}{*}{ Missing } & 1 & $1.45 \%$ & Nonfamily manager & 56 & $81.16 \%$ \\
\hline & & & Family manager & 11 & $15.94 \%$ \\
\hline Panel A2: Is the CEO from the controlling family? & & & Founder & 2 & $2.90 \%$ \\
\hline Yes & 52 & $75.36 \%$ & & & \\
\hline No & 17 & $24.64 \%$ & & & \\
\hline
\end{tabular}

Continues 
Table 1 (continued)

\begin{tabular}{|c|c|c|c|c|c|}
\hline & $\mathrm{n}$ & $\%$ & & $\mathrm{n}$ & $\%$ \\
\hline Panel A3: Family involvement in ownership* & & & Panel B3: Respondent's tenure & & \\
\hline The family owns $100 \%$ of the shares & 46 & $66.67 \%$ & Between 1 and 5 years & 10 & $14.49 \%$ \\
\hline \multirow[t]{2}{*}{ There are majority and minority shareholders } & 23 & $33.33 \%$ & Between 6 and 10 years & 16 & $23.19 \%$ \\
\hline & & & More than 10 years & 43 & $62.32 \%$ \\
\hline \multicolumn{6}{|l|}{ Panel A4: Firm age } \\
\hline Between 1 and 20 years & 3 & $4.35 \%$ & & & \\
\hline Between 21 and 50 years & 13 & $18.84 \%$ & & & \\
\hline More than 51 years & 52 & $75.36 \%$ & & & \\
\hline Missing & 1 & $1.45 \%$ & & & \\
\hline
\end{tabular}

Note. * Family involvement in ownership is a control variable in the model and was measured as a dummy variable indicating whether the controlling family holds $100 \%$ of the family business' shares (value $=1$ ).

\section{Measures}

The study combines measures obtained in a survey that contains validated scales that were used in studies published in the FB literature with archival information related to FB performance (See Table 2).

Table 2

Description of the measurement of the independent and dependent variables

\begin{tabular}{|c|c|c|c|c|c|}
\hline Construct & Variable & Item & Scale & Source & Reference \\
\hline \multirow[b]{2}{*}{$\begin{array}{l}\text { Family } \\
\text { involvement in } \\
\text { management }\end{array}$} & Family CEO & $\begin{array}{l}\text { Is the CEO (or another executive that holds } \\
\text { the highest position in the business) from the } \\
\text { controlling families? }\end{array}$ & Dummy & Survey & \multirow[b]{2}{*}{$\begin{array}{l}\text { D'Allura (2019); } \\
\text { Minichilli, } \\
\text { Corbetta and } \\
\text { MacMillan } \\
(2010)\end{array}$} \\
\hline & $\begin{array}{l}\text { The ratio of } \\
\text { family } \\
\text { managers in } \\
\text { the TMT }\end{array}$ & $\begin{array}{l}\text { (i) Number of executives in the Top } \\
\text { Management Team (TMT). } \\
\text { (ii) Number of executives in the TMT that are } \\
\text { from the controlling families. } \\
\text { Members of the Top Management Team } \\
\text { (TMT) are those executives that report directly } \\
\text { to the CEO or to a similar executive that holds } \\
\text { the highest position in the organization, } \\
\text { including the CEO. }\end{array}$ & $\begin{array}{l}\text { The ratio of } \\
\text { ii/i (from zero } \\
\text { to one) }\end{array}$ & Survey & \\
\hline $\begin{array}{l}\text { Stewardship- } \\
\text { oriented } \\
\text { culture }\end{array}$ & $\begin{array}{l}\text { Stewardship- } \\
\text { oriented } \\
\text { culture (4 } \\
\text { reflective- } \\
\text { items) }\end{array}$ & $\begin{array}{l}\text { STEWcult_1. Your company allows managers } \\
\text { to reach their full potential in terms of } \\
\text { contributing to the company. } \\
\text { STEWcult_2. Your company promotes a } \\
\text { professionally orientated workplace. } \\
\text { STEWcult_3. Your company inspires } \\
\text { managers' care and loyalty to the company. } \\
\text { STEWcult_4. Your company encourages a } \\
\text { collectivist culture focused on the business } \\
\text { group rather than an individualistic culture. }\end{array}$ & $\begin{array}{l}\text { Likert-type } \\
\text { scale ( } 5 \\
\text { points) }\end{array}$ & Survey & $\begin{array}{l}\text { Zahra et al. } \\
\text { (2008) }\end{array}$ \\
\hline
\end{tabular}


Table 2 (continued)

\begin{tabular}{llllll}
\hline Construct & Variable & Item & Scale & Source & Reference \\
\hline \multirow{2}{*}{$\begin{array}{l}\text { Financial } \\
\text { performance }\end{array}$} & $\begin{array}{l}\text { ROA (Return } \\
\text { on Assets) }\end{array}$ & The ratio of EBIT and Total Assets. ${ }^{\text {a }}$ & Percentage & $\begin{array}{l}\text { Archival } \\
\text { (EMIS } \\
\text { database) }\end{array}$ & $\begin{array}{l}\text { Martins, } \\
\text { Diniz and } \\
\text { Miranda } \\
(2012)\end{array}$ \\
\cline { 2 - 7 } & $\begin{array}{l}\text { ROS (Return } \\
\text { on Sales) }\end{array}$ & $\begin{array}{l}\text { The ratio of Net Profit after Tax and Net } \\
\text { Operating Sales. }{ }^{a}\end{array}$ & Percentage & $\begin{array}{l}\text { Archival } \\
\text { (EMIS } \\
\text { database) }\end{array}$ &
\end{tabular}

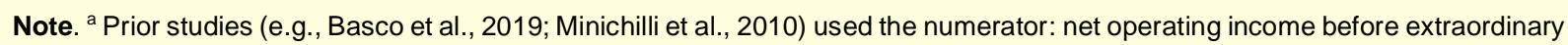
items. For ROA, we used EBIT as the numerator, since NOPAT (Net Operating Income after Taxes) was not available in the database, and we used profit after tax for ROS.

Family involvement in management. We used two indicators for family involvement in management. One is the percentage of family managers in the Top Management Team (TMT Family Ratio), also treated as a quadratic variable, and the other is a dummy variable measuring if a family member is the CEO of the FB (Family CEO).

Stewardship-oriented culture. We captured stewardship-oriented culture (Stewardship) based on a 4item multidimensional scale adapted from Zahra et al. (2008), which indicates "the degree to which a stewardship culture exists within the family firm" (p. 1042). This latent variable presented convergent validity and composite reliability based on the following parameters: (a) 0.897 for Composite Reliability and (b) 0.686 for Average Variance Extracted (AVE).

Performance. We used two indicators that have been widely used in the FB literature for the familiness-performance relationship (De Massis et al., 2015; Garcia-Castro \& Aguilera, 2014; Minichilli et al., 2010; Rutherford et al., 2008; Wagner et al., 2015), these being: (a) Return on Sales (ROS) and (b) Return on Assets (ROA). All these indicators were obtained from the EMIS® database, and for six firms we complemented them by using the information available in the Valor ${ }^{\circledR} 1000$ publication. Financial performance was measured as a percentage for 2016. Return on Sales was measured as the ratio between the net profit after taxes and total net operating sales. Return on Assets was measured as the ratio between the EBIT (Earnings before Interests and Taxes) and total assets. We used these two indicators of performance because they might capture different facets of performance that are influenced by different decisions of the TMT. We considered industry-adjusted measures, which were calculated by subtracting the firm performance measure from the median industry level (De Massis et al., 2015), taking into account the firms' activity described in the EMIS ${ }^{\circledR}$ database, which includes the firms' financial information for 2016. We estimated the performance measures adjusted with respect to the median of the industry. To do this for each firm in our sample, we paired the firms and their competitors, matching the first activity of the firms in our sample with the other firms' activity description. This procedure is relevant due to differences between industries regarding, for example, market opportunities and constraints. For five firms, due to the lack of information in the EMIS ${ }^{\circ}$ database about competitors that operate in the same industry as the firms, we did not adjust their profitability measures in relation to their industry. 
Controls. We controlled the FB's performance by the firm's size, which was measured as the logarithm of total assets, and by the firm's age (measured as age in years). We also controlled for family involvement in ownership using a dummy variable indicating if the controlling family holds $100 \%$ of the family business' shares (value $=1$ ). These variables were also used in prior studies (e.g., Basco et al., 2019; Kim \& Gao, 2013).

\section{Data analysis methods}

We applied the Structural Equation Modeling (SEM-SmartPLS) multivariate technique to test the theoretical model. We used the variance-based SEM technique in the SmartPLS software because it has a number of advantages (Hair, Hult, Ringle, \& Sarstedt, 2013; Hair, Sarstedt, Ringle, \& Gudergan, 2017; Nitzl, 2016; Sarstedt, Ringle, Smith, Reams, \& Hair, 2014): (a) it does not impose the data distribution assumptions as in regression analysis, and in our model some items have a nonnormal distribution, such as stewardship-oriented culture; and (b) it is possible to estimate complex models reliably with fewer observations.

We checked the post-hoc results in the GPower 3.1.9.2 software (Faul, Erdfelder, Lang, \& Buchner, 2007) to evaluate the application of SmartPLS with our sample size, as suggested by Nitzl (2016). We obtained a statistical power higher than 0.8 (less than 20\% type II error) for a minimum sample of 52 respondents, based on the following parameters (Nitzl, 2016): (a) 5\% significance level (type-I error); (b) detection of strong relative effect (f2 higher than 0.35); and (c) having eight predictors in our model. Therefore, despite our small sample size, our model can show statistically significant relationships.

\section{Data Analysis}

\section{Descriptive statistics}

We present the descriptive statistics of the constructs in Table 3. We show the firms' financial information for 2016 in terms of Total Operating Revenue, Total Assets, and Total Equity. The firms' Total Assets range between 13.91 million and 14.80 billion reais (BRL). We use the logarithm of Total Assets as a control variable for firm size. 
Table 3

\section{Sample descriptive statistics}

\begin{tabular}{lccccc}
\hline Variable & $\mathrm{n}$ & Mean & Std. Dev. & Min & Max \\
\hline TOpRev_16 (million BRL) & 69 & 694.07 & 886.65 & 2.38 & $4,228.95$ \\
Tassets_16 (million BRL) $^{*}$ & 69 & 878.02 & $1,990.97$ & 13.91 & $14,801.59$ \\
Tequity_16 (million BRL) & 69 & 273.58 & 487.01 & $-1,645.36$ & $2,648.36$ \\
EBIT_16 (\%) & 69 & 50.11 & 103.05 & -108.21 & 467.42 \\
Net_profit_16 (\%) & 69 & 2.88 & 226.07 & $-1,746.94$ & 303.41 \\
ROS_16 (\%) & 69 & 2.43 & 14.38 & -49.97 & 37.55 \\
ROA_16 (\%) & 69 & 7.40 & 14.40 & -50.62 & 73.82 \\
STEWcult_1 & 69 & 3.81 & 1.00 & 1.00 & 5.00 \\
STEWcult_2 & 69 & 3.67 & 1.11 & 1.00 & 5.00 \\
STEWcult_3 & 69 & 4.20 & 0.80 & 2.00 & 5.00 \\
STEWcult_4 & 69 & 3.90 & 1.05 & 1.00 & 5.00 \\
\hline
\end{tabular}

Note. TOpRev 16 (Total Operating Revenue in 2016), Tassets 16 (Total Assets in 2016), Tequity 16 (Total Equity in 2016), EBIT_16 (Earnings before Interests and Taxes in 2016), Net_profit_16 (Profit after taxes in 2016) ROS_16 (Return on Sales in 2016), ROA_16 (Return on Assets in 2016). STEWcult_1 to STEWcult_4 are stewardship-oriented culture indicators. On July 28 , 2019, US\$ 1 was equivalent to BRL 3.78 .

* Firm's size is a control variable in the model and was measured as the logarithm of total assets. Of these firms, $52.17 \%$ are audited.

Additionally, we present the statistics of the performance measures, which are ROS (Return on Sales) and ROA (Return on Assets). The average scores for these variables are $2.43 \%$ and $7.40 \%$, respectively. It is important to mention that in our analysis, we used the industry-adjusted performance measure, which was estimated by subtracting the firm's performance from the median in the industry (see second subsection of Data Analysis).

Concerning stewardship-oriented culture, the highest mean score the respondents indicated was for the firm inspiring managers' care and loyalty to the company (4.20) and the lowest mean score was for the statement related to promoting a professionally-orientated workplace (3.67).

\section{Measurement model assessment}

We validated the measurement model for the analysis of reflective measurement models in accordance with Hair, Hult, Ringle and Sarstedt (2013). The evaluation of reflective models includes convergent validity, internal consistency, and discriminant validity. We conducted this evaluation exclusively for the stewardship-oriented culture latent variable since the other variables are single items that are directly observable variables. Our results meet the criteria suggested by Hair et al. (2013) regarding the validity and reliability of stewardship-oriented culture, whose parameters we present in second subsection of Methodology. According to Hair et al. (2013): (a) composite reliability should be above 0.7 ; (b) outer loadings should be above 0.7 or at least above 0.4; and (c) the Average Variance Extracted should be above 0.5. In terms of the discriminant validity, we used both cross-loadings and the Fornell-Larcker criterion (Fornell \& Larcker, 1981). 
For the Fornell-Larcker matrix, the diagonal (which is the square root of the AVE) of each latent variable is expected to be greater than the highest correlations between the latent variables (Hair et al., 2013). After applying these analyses, we validated the stewardship-oriented culture latent variable.

\section{Structural model analysis}

We analyzed the structural model following a set of steps (Hair et al., 2013). In the first step, we analyzed multicollinearity based on the Variance Inflation Factor (VIF). Our results indicate values below 2.24 (e.g., for the ROS dependent variable in Model 7), while the recommendation is lower than five. Second, we analyzed the statistical significance of the structural path coefficients by running the bootstrapping procedure (1,000 subsamples, bias-corrected confidence level, and two-tailed tests). Additionally, we calculated the $\mathrm{R}^{2}$, which indicates the percentage of a dependent variable's variance that is explained by the independent variables and moderators in the model. We also present the results for the adjusted coefficient of determination (Adj $\mathrm{R}^{2}$ ), as suggested by Hair et al. (2013).

Our model shows a quadratic effect of the ratio of family managers in the TMT (TMT Family Ratio $^{2}$ ) and has a moderator variable, which is stewardship-oriented culture. Hair et al. (2013) indicate three different procedures for moderator effects. The three procedures are the product indicator approach, the two-step approach, and the orthogonal. Hair et al. (2013) explain that for reflective constructs the two-step approach can be used to reveal the significance of the moderating effect, while the orthogonal approach is recommended to minimize estimation bias (due to multicollinearity between the predictive variables and the multiplicative term of the interaction) and maximize predictive ability. Due to the objectives of this study, we ran the analysis based on the orthogonal approach for moderation. The orthogonalization approach uses standard residuals as indicators for the interaction term (Hair et al., 2013). Additionally, we ran two different models based on two different financial industry-adjusted performance measures (e.g., De Massis et al., 2015), which are (a) Return on Sales (ROS) and (b) Return on Assets (ROA). We present the results in Tables 4 and 5. We present seven models that were built step by step considering the inclusion of the independent and moderating variables. In Model 1, the results are presented for the presence of a family CEO, and Model 7 includes all the independent and moderating variables. 
Table 4

\section{Structural model - ROS dependent variable}

\begin{tabular}{|c|c|c|c|c|c|c|c|}
\hline $\begin{array}{l}\text { Dependent variable: ROS } \\
\text { Path coefficients } \\
n=69\end{array}$ & Model 1 & Model 2 & Model 3 & Model 4 & Model 5 & Model 6 & Model 7 \\
\hline \multicolumn{8}{|l|}{ Controls } \\
\hline Firm size & 0.172 & 0.135 & 0.136 & 0.111 & 0.073 & 0.076 & 0.079 \\
\hline Firm age & -0.047 & -0.076 & -0.072 & -0.081 & -0.095 & -0.091 & -0.090 \\
\hline Ownership & 0.092 & 0.150 & 0.148 & 0.142 & 0.132 & 0.131 & 0.131 \\
\hline \multicolumn{8}{|l|}{ Independent variables } \\
\hline Family CEO & $0.252 \dagger$ & $0.345^{\star}$ & $0.356^{\star}$ & 0.301 & $0.323^{*}$ & $0.347 \dagger$ & 0.356 \\
\hline TMT Family Ratio & & $-0.246 \dagger$ & -0.272 & -0.257 & -0.245 & -0.294 & -0.298 \\
\hline TMT Family Ratio ${ }^{2}$ & & & 0.038 & 0.041 & & 0.067 & 0.067 \\
\hline Stewardship & & & & 0.010 & 0.014 & -0.003 & -0.005 \\
\hline \multicolumn{8}{|l|}{ Interactions Stewardship } \\
\hline Family CEO * Stewardship & & & & & $-0.441^{\star \star \star}$ & $-0.445^{\star \star \star}$ & $-0.455^{\star \star}$ \\
\hline TMT Family Ratio * Stewardship & & & & -0.174 & & & 0.029 \\
\hline $\mathrm{R}^{2}$ & 0.074 & 0.117 & 0.119 & 0.139 & 0.284 & 0.288 & 0.288 \\
\hline Adj $R^{2}$ & 0.016 & 0.047 & 0.033 & 0.025 & 0.202 & 0.193 & 0.180 \\
\hline
\end{tabular}

Note. $† 0.10$-level. ${ }^{*} 0.05$-level. ${ }^{* *} 0.01$-level. ${ }^{* * *} 0.001$-level.

Table 5

\section{Structural model - ROA dependent variable}

\begin{tabular}{|c|c|c|c|c|c|c|c|}
\hline $\begin{array}{l}\text { Dependent variable: } R O A \\
\text { Path coefficients } \\
n=69\end{array}$ & Model 1 & Model 2 & Model 3 & Model 4 & Model 5 & Model 6 & Model 7 \\
\hline \multicolumn{8}{|l|}{ Controls } \\
\hline Firm size & 0.114 & 0.109 & 0.109 & 0.081 & 0.054 & 0.055 & 0.049 \\
\hline Firm age & 0.099 & 0.095 & 0.096 & 0.058 & 0.049 & 0.052 & 0.047 \\
\hline Ownership & $0.237^{\star}$ & $0.246^{\star \star}$ & $0.245^{\star}$ & $0.240^{\star}$ & $0.228^{*}$ & $0.225^{\star}$ & $0.224^{\star}$ \\
\hline \multicolumn{8}{|l|}{ Independent variables } \\
\hline Family CEO & 0.163 & 0.178 & 0.180 & 0.138 & 0.183 & 0.208 & 0.179 \\
\hline TMT Family Ratio & & -0.039 & -0.045 & -0.062 & -0.045 & -0.100 & -0.091 \\
\hline TMT Family Ratio² & & & 0.008 & 0.061 & & 0.078 & 0.080 \\
\hline Stewardship & & & & -0.120 & -0.111 & -0.136 & -0.133 \\
\hline \multicolumn{8}{|l|}{ Interactions Stewardship } \\
\hline Family CEO * Stewardship & & & & & $-0.403^{\star \star}$ & $-0.407^{\star *}$ & $-0.370^{*}$ \\
\hline TMT Family Ratio * Stewardship & & & & $-0.272 \dagger$ & & & -0.105 \\
\hline $\mathrm{R}^{2}$ & 0.086 & 0.087 & 0.087 & 0.150 & 0.239 & 0.243 & 0.250 \\
\hline Adj $R^{2}$ & 0.029 & 0.015 & 0.000 & 0.037 & 0.151 & 0.143 & 0.135 \\
\hline
\end{tabular}

Note. 1: † 0.10-level. * 0.05 -level. ${ }^{* *} 0.01$-level. ${ }^{* \star *} 0.001$-level. 


\section{The relationship between family CEO and firm performance}

Table 4 shows a statistically significant and positive association between Family CEO and ROS (Models 1, 2, 3, 5, and 6), thus supporting H1. However, our results do not support a positive association between the presence of a family CEO and ROA (see Table 5).

This result is aligned with previous empirical evidence that a family CEO may behave altruistically and as a steward (e.g., loyalty, commitment), serving the best interests of the principals (GonzálezCruz \& Cruz-Ros, 2016; Miller \& Le Breton-Miller, 2006; Minichilli et al., 2010). In alignment with empirical evidence from prior literature, we suggest that family leadership, concerning the $\mathrm{CEO}$ position, has a positive influence on the FB's performance. Some authors interpret this association as the bright side of family involvement in the firm (Minichilli et al., 2010; Villalonga $\&$ Amit, 2006).

\section{The relationship between the ratio of family managers in the TMT and firm performance}

Our results contradict hypothesis $\mathrm{H} 2 \mathrm{a}$ regarding the positive association between family involvement in management and FB performance. Our analysis mainly supports a negative association between the ratio of family managers in the TMT and ROS (only in Model 2) and a nonsignificant association between TMT Family Ratio and ROA. In addition, unlike in prior literature, our result does not support a nonlinear association, whose discussion has been based on the inverted U-shape relationship (expertise and competences mix among family and nonfamily managers) (González-Cruz \& Cruz-Ros, 2016; Sciascia \& Mazzola, 2008). Therefore, hypotheses $\mathrm{H} 2 \mathrm{a}$ and $\mathrm{H} 2 \mathrm{~b}$ were not supported. Based on a study of non-listed Spanish firms focused on the board of directors, Arosa, Iturralde, and Maseda (2010) claim that a significant relationship between involvement and performance cannot be assumed since individuals have particular roles and characteristics (e.g., behavioral, expertise). Another interpretation for this nonsignificant result might come from the sample's characteristics. Most of the firms of the sample are large-sized, founded more than 50 years ago and owned by the second and third generations of the family. This means that those FBs are able to hire nonfamily managers with expertise and that those family managers involved in the firm might also show professional skills that are aligned with a top management position. In addition, those complex and mature FBs might also have implemented formal governance mechanisms that are expected to suppress family agency conflicts (e.g., Purkayastha, Veliyath, \& George, 2019). Therefore, different from our hypotheses and based on our sample's characteristics, family involvement in management might not induce a higher level of performance $(\mathrm{H} 2 \mathrm{a})$, even when there is a mix of family and nonfamily expertise (H2b).

\section{Moderation by a stewardship-oriented culture}

Table 4 and Table 5 show a significant moderating effect for the association between the presence of a family CEO and performance (H3) and not for the ratio of family managers in the TMT

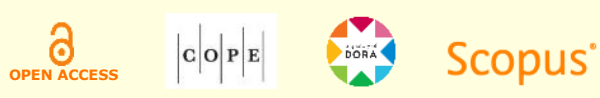


(H4). These results were supported by both dependent variables, these being ROS (Models 4, 5, and 6) and ROA (Models 4, 5, and 6). In Figure 2 (Panel A), we show that firms without a family $\mathrm{CEO}$ and that have a higher stewardship-oriented culture perform slightly better than those with a lower stewardship-oriented culture, in terms of ROS. The difference is much more representative with the presence of a family $\mathrm{CEO}$, however not as we hypothesized. A FB that has a family CEO and a low level of stewardship-oriented culture shows a higher performance than one that has a family CEO and a high level of stewardship-oriented culture. It could be that through excessive trust and absence of formal monitoring and incentive systems, principal-agent costs and within family agency costs are not controlled.

Additionally, the difference among the points on the graph (Figure 2, Panel A) is much more representative in the case of a low level of stewardship-oriented culture than for a high level. We expected a family CEO who theoretically behaves as a steward to increasingly influence performance in the case of a high level of stewardship-oriented culture, which was not supported by our results. This finding contradicts previous literature that suggests that stewardship governance and culture improve the financial performance of FBs (James et al., 2017; Madison et al., 2016; Madison, Kellermanns, \& Munyon, 2017). It might be the case that a stewardshiporiented culture relates to a low level of adoption of formal monitoring mechanisms. Therefore, when there is a family CEO, stewardship can foster (instead of curbing) family agency problems, which consequently decreases FB performance. On the other hand, for a nonfamily CEO, a stewardship-oriented culture might help to mitigate type-I agency costs and to align interests more easily, which consequently increases FB performance. Another element that might generate these contradictory results is that we have not considered the level of CEO autonomy and CEO stewardship behavior (Henssen et al., 2014).

Finally, a stewardship-oriented culture's moderating effect on the association between the ratio of family managers in the TMT and FB performance was not statistically significant at the 5\% significance level (H4). Based on this result, a stewardship-oriented culture might not enhance the bright side or suppress the dark side of familiness derived from family managers' involvement in the TMT (Kellermanns et al., 2012). This finding contradicts Kim and Gao (2013), who found a moderating effect of family-longevity goals on the FIM-performance relationship. However, Kim and Gao (2013) focused on young FBs (about 65\% with less than 10 years) and also on small and medium FBs, while our study focused on medium and large FBs founded more than 50 years ago and which are owned by second and third generations. Therefore, due to the size and underlying complexity of the family businesses in our sample, there might be other antecedents regarding governance that are expected to have an influence on the performance of those FBs. For instance, the design of monitoring and incentive, which are agency-type governance mechanisms, might deserve further investigations (e.g., Madison et al., 2017). On the other hand, based on a metaanalysis, O'Boyle, Pollack and Rutherford (2012) show that at a national level, power distance and collectivist cultures do not moderate the FIM-performance relationship. Our study contributes to this debate at an intra-firm cultural level and opens the debate if a stewardshiporiented culture is a crucial moderator for FIM-performance relationship.

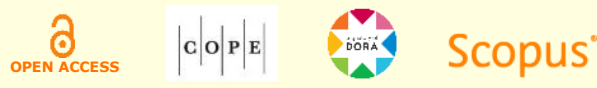




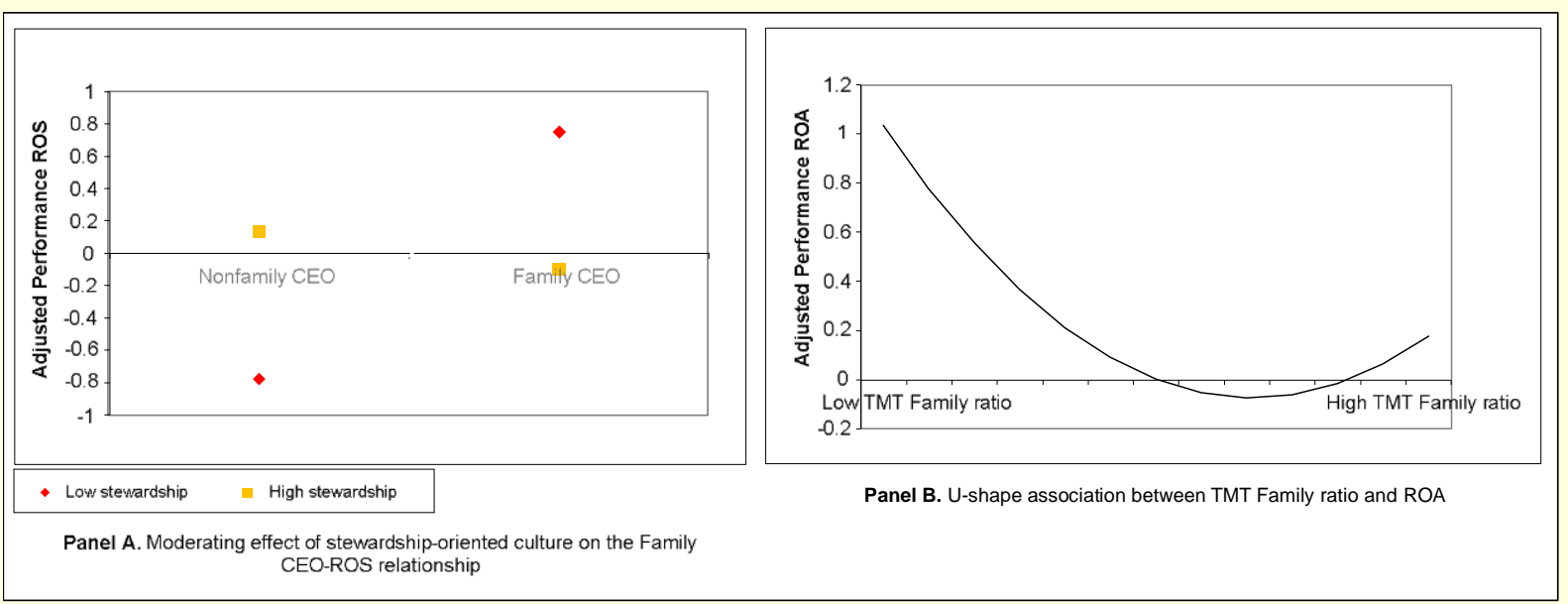

Figure 2. Moderating and quadratic effects

Panel A was plotted using the coefficients of the multivariate model, controlling for the other variables (see Tables 4 and 5). We used the coefficients of Model 5 to plot the graph. Panel B was plotted using the coefficients of the multivariate model. We used the coefficients of Model 6 to plot the graph, considering the results for the subsample of 64 firms discussed in the additional analysis subsection.

\section{Additional analysis}

To strengthen our findings, we ran additional analysis based on a subsample of 64 family businesses that were not facing financial distress. Therefore, we excluded from our sample four firms that had negative equity and one that had Return on Sales lower than $-30 \%$. In the additional analysis, we ran seven models similar to Table 4 and Table 5, which we detail below. The results are presented in Appendix.

First, the results support the positive association between Family CEO and performance (H1), considering ROA and ROS as dependent variables. As in the sample analysis, our additional analyses support the moderating effect of stewardship on the relationship between Family CEO and performance $(\mathrm{H} 3)$. This result confirms the findings from the sample analysis and extends prior literature (e.g., Kim \& Gao, 2013) concerning the moderating effect on the Family CEO and performance relationship.

With respect to the ratio of family managers in the TMT, the results of the additional analyses contradict hypothesis $\mathrm{H} 2 \mathrm{~b}$ and support a U-shape association between TMT Family Ratio and performance, both for the ROS and ROA dependent variables. In Figure 2 (Panel B), we demonstrate that a predominance of one subgroup in the TMT, whether family managers or nonfamily managers, is related to a higher level of Return on Sales and Return on Assets. On the other hand, when the TMT mixes both family and nonfamily managers, Figure 2 (Panel B) shows a lower level of performance in terms of ROA. These results contradict the hypothesis regarding an inverted-U-shaped association and support a U-shaped relationship. A TMT composed exclusively of nonfamily managers presents the highest level of performance, which is consistent with Minichilli et al. (2010), who developed a study using small and medium Italian FBs (Chirico \& Bau', 2014; Sciascia \& Mazzola, 2008). 
Minichilli et al. (2010) claim that "tensions and conflicts emerge when both 'principal' (owners and family members) and 'agents' (nonfamily managers) coexist in the same decision-making arena” (p. 217). In FBs, there are two basic subgroups, which are family and nonfamily managers. While family managers share common values related to their relatives and emotional attachment to the firm, nonfamily managers share professional values and the feeling that they are outsiders of the family clan (Davis et al., 2010; Lubatkin et al., 2005; Verbeke \& Kano, 2012). This argument is aligned with the faultlines concept suggested by Minichilli et al. (2010), which determines that faultlines occur in a Top Management Team that is composed of both family and nonfamily managers. These faultlines depend on the schisms due to the presence of both family and nonfamily managers, which has been discussed in the TMT heterogeneity literature (Certo, Lester, Dalton, \& Dalton, 2006; Lau \& Murnighan, 1998). For instance, these schisms might relate with tensions regarding short and long term outcomes, economic and noneconomic goal tradeoffs (Berrone, Cruz, \& Gomez-Mejia, 2012; Gomez-Mejia et al., 2011), as well as the design of agency and stewardship mechanisms that fits the manager's behaviors (James et al., 2017; Madison et al., 2017). Therefore, these schisms can cause conflicts between the subgroups of family and nonfamily managers, which would negatively affect FB performance. Recently, Basco, Campopiano, Calabrò and Kraus (2019) showed evidence of a U-shaped association between the ratio of family members in the board of directors and performance, in a study developed using small and medium Spanish FBs owned mainly by first and second generations, whose arguments were also based on the faultlines theory. Hence, our study corroborates the findings from Basco et al. (2019) and Minichilli et al. (2010) regarding the existence of faultlines in the management team of medium and large FBs mainly from second and third generations. Finally, in terms of the moderating effect on the FIM-performance relationship, our results from the additional analysis do not support any significant relationship (H4) suggesting that stewardship does not suppress family agency problems neither mitigate the conflicts between family and nonfamily managers in later generations and more complex FBs.

\section{Discussion and Conclusions}

This study discusses the association between family involvement in management and the FB's financial performance, considering stewardship-oriented culture as a moderator of this relationship. Although much evidence on this subject can be found in the literature, prior studies have offered contradictory findings, and one of the reasons is that few studies have contextualized the family involvement and performance relationship by considering ability and essence dimensions simultaneously (Basco, 2013; Basco \& Voordeckers, 2015). For instance, recent studies have looked at family-longevity goals (Kim \& Gao, 2013) and objective achievement perceptions (Basco et al., 2019). We considered stewardship-oriented culture as a resource that is discussed in the familiness theoretical approach, and that might help to address the call to examine family essence aspects and the moderators that might enhance or suppress this relationship in the family business field.

In line with prior literature (González-Cruz \& Cruz-Ros, 2016; Minichilli et al., 2010), we found that family involvement in management is associated with FB performance, in particular given

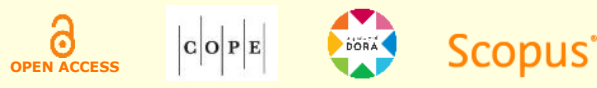


the presence of a family CEO. Unlike in the previous literature, we considered the moderating role of a stewardship-oriented culture in this relationship, since it was considered a contextual element that might enhance the benefits or suppress the typical agency costs related to family involvement in management. This paper suggests that a high level of stewardship-oriented culture, which means a collective, supportive, and caring environment, combined with the presence of a family CEO, produces a low level of performance (ROS and ROA). However, in the case of a low level of stewardship-oriented culture, the presence of a family CEO enhances the FB's performance.

Therefore, we find that a stewardship-oriented culture might not be able to mitigate family agency conflicts in the case of the presence of a family CEO. However, we do observe that a stewardship culture might suppress type-I agency conflicts when a nonfamily CEO is present in private FBs of medium or large size and of a later generation; differences in family involvement in management are still additional variables to consider when explaining family firm performance.

Additionally, the results for the association between the ratio of family managers in the TMT and the FB's performance suggest a nonlinear relationship, in particular, a U-shaped one, which was supported by the additional analysis. In line with prior empirical evidence (Minichilli et al., 2010), we find that the presence of only nonfamily managers or family managers in the TMT is positively associated with the FB's performance. Our findings indicate that when there are two almost equal groups of family and nonfamily managers (U-shape) in the TMT, conflicts and tensions between these family and nonfamily manager subgroups have a negative influence on firm performance (Basco et al., 2019; Lubatkin et al., 2005; Minichilli et al., 2010).

This study contributes to the family business literature in multiple ways. First, as called for by Basco (2013) and the recent advancements in the field (e.g., Basco et al., 2019; Kim \& Gao, 2013), we analyzed both the composition of the TMT and family essence as determinants of family firm performance. Family essence was studied in terms of the stewardship-oriented culture. The focus on a cultural dimension such as stewardship is crucial since it might show different findings from prior literature such as Basco et al. (2019), which have used behavioral agency arguments. Notably, the stewardship lens has attracted recent attention from scholars as an element to fit family managers' behaviors as well as to explain family firm performance (e.g., James et al., 2017).

Second, this study focuses on differences related to family involvement in management within FBs. The level of family involvement in the management of the FB in terms of whether a family CEO is present and the ratio of family managers in the TMT has, as far as we know, not been investigated in Brazilian FBs.

Third, we also contribute to the literature in terms of using objective measures for firm performance, and we conduct the research using a sample of medium and large FBs from an emerging economy (Kim \& Gao, 2013). Previous studies have mainly focused on small and medium enterprises from Europe and the United States, which might have different institutional and cultural characteristics that tend to influence FBs (Basco, 2013; Wagner et al., 2015). Family

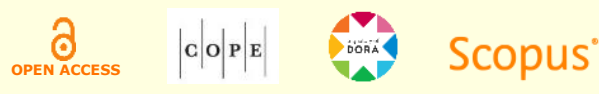


firms from emerging economies such as Brazil may have a concentrated level of family ownership and might be more likely to present a one-tier governance model (Frezatti et al., 2017; IBGC, 2019). In addition, FBs that operate in Brazil may be influenced by a particular national culture in terms of higher levels of power distance, collectivism, and risk avoidance (Hofstede, 2001), which together affect the way family members influence business decisions and consequently performance.

Despite the contributions that this paper provides, our findings are subject to some limitations. First, this study is developed based on cross-sectional data that combine survey data (family involvement in management and stewardship) with archival data (financial information). As a result of the research design and the tests we carried out, we do not think that the data suffer from common method variance (Podsakoff et al., 2012). However, as we focus on cross-sectional data, we are not able to draw causal conclusions.

In addition, we used a convenience sample of medium and large private Brazilian FBs, which involves limitations in terms of generalization. Although we developed analyses using a small sample size $(n=69)$, due to the complexity of the information and the availability of the archival data, we consider the sample to be relevant for this study especially with respect to private FBs. Despite these considerations, the results show statistical significance, while some support and others contradict previous literature. Our study focused on two profitability measures, ROA and ROS, which have been commonly used by previous research (e.g., De Massis et al., 2015; GarciaCastro \& Aguilera, 2014; Minichilli et al., 2010).

We suggest future avenues for research. First, future studies could consider the coexistence of both stewardship and agency governance mechanisms as moderators for the relationship between family involvement in management and performance to explain the conflicting findings in prior literature (e.g., Chrisman, 2019; Madison et al., 2017). Family-longevity goals might enhance FIM-performance relation in young small and medium FBs (e.g., Kim \& Gao, 2013), however in large FBs there might be other mechanisms, such as agency-type mechanisms, that enhance this relationship. In addition, there is a need for more studies to investigate the faultlines issue, particularly for large and later generation FBs, which could bring more insights to explain family involvement and performance relation (e.g., Basco et al., 2019; Minichilli et al., 2010).

In terms of research design, we suggest future studies to examine these associations based on performance change measures such as change in profitability or growth of total operating revenue (e.g., Rutherford et al., 2008), since the effect of stewardship on performance might be in the long term (Corbetta \& Salvato, 2004). Self-reported performance measures (rated as relative performance compared with the main competitor) might also be used (e.g., González-Cruz \& Cruz-Ros, 2016; Rutherford et al., 2008; Sciascia \& Mazzola, 2008) in periods of economic crisis despite their subjectivity. Additionally, as FBs have both financial and nonfinancial goals related to socioemotional wealth preservation (Berrone et al., 2012), future studies might consider both financial and nonfinancial performance measures as dependent variables. Finally, longitudinal studies could provide a complementary view regarding how the familiness dimensions related to the family's involvement in management influence FB performance, which could capture the

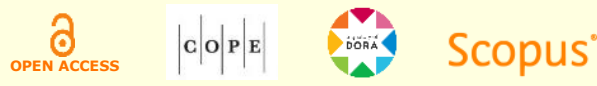


bright and dark sides of family involvement in the firm in the long term (Lubatkin et al., 2005; Minichilli et al., 2010; Villalonga \& Amit, 2006).

\section{Note}

${ }^{1}$ EMIS is a worldwide database that includes analytical data and reports of organizations for over 125 countries emerging markets (https://www.emis.com/who-we-are).

\section{References}

Anderson, R. C., \& Reeb, D. M. (2003). Founding-family ownership and firm performance: Evidence from the S\&P 500. The Journal of Finance, 58(3), 1301-1328. https://doi.org/10.1111/1540-6261.00567

Arosa, B., Iturralde, T., \& Maseda, A. (2010). Outsiders on the board of directors and firm performance: Evidence from Spanish non-listed family firms. Journal of Family Business Strategy, 1(4), 236-245. https://doi.org/10.1016/j.jfbs.2010.10.004

Banco Nacional de Desenvolvimento Econômico e Social. (n.d.). Porte de empresa. Retrieved from https://www.bndes.gov.br/wps/portal/site/home/financiamento/guia/porte-de-empresa

Basco, R. (2013). The family's effect on family firm performance: A model testing the demographic and essence approaches. Journal of Family Business Strategy, 4(1), 42-66. https://doi.org/10.1016/j.jfbs.2012.12.003

Basco, R., Campopiano, G., Calabrò, A., \& Kraus, S. (2019). They are not all the same! Investigating the effect of executive versus non-executive family board members on firm performance. Journal of Small Business Management, 57(sup2), 637-657. https://doi.org/10.1111/jsbm.12535

Basco, R., \& Voordeckers, W. (2015). The relationship between the board of directors and firm performance in private family firms: A test of the demographic versus behavioral approach. Journal of Management $\mathcal{E}$ Organization, 21(4), 411-435. https://doi.org/10.1017/jmo.2015.23

Berrone, P., Cruz, C., \& Gomez-Mejia, L. R. (2012). Socioemotional wealth in family firms: Theoretical dimensions, assessment approaches, and agenda for future research. Family Business Review, 25(3), 258-279. https://doi.org/10.1177/0894486511435355

Beuren, I. M., Politelo, L., \& Martins, J. A. S. (2016). Influence of family ownership on company performance. International Journal of Managerial Finance, 12(5), 654-672. https://doi.org/10.1108/ijmf-09-2014-0151

Brandt, E., Kroenke, A., \& Pletsch, C. (2018). Efeito da gestão familiar na avaliação do desempenho da empresa: Evidências do Brasil. Revista Catarinense da Ciência Contábil, 17(52), 41-55. https://doi.org/10.16930/2237$7662 /$ rccc.v17n52.2727

Bressan, A. A., Schiehll, E., Procianoy, J. L., \& Castro, L. R. K. de. (2019). Perspectivas da pesquisa em governança de empresas familiares no Brasil. Revista de Administração Contemporânea, 23(6), 696-702. https://doi.org/10.1590/1982-7849rac2019190331

Calabrò, A., Campopiano, G. and Basco, R. (2017), Principal-principal conflicts and family firm growth: The moderating role of business family identity. Journal of Family Business Management, 7(3), 291-308. https://doi.org/10.1108/JFBM-02-2017-0005

Certo, S. T., Lester, R. H., Dalton, C. M., \& Dalton, D. R. (2006). Top management teams, strategy and financial performance: A meta-analytic examination. Journal of Management Studies, 43(4), 813-839. https://doi.org/10.1111/j.1467-6486.2006.00612.x

Chirico, F., \& Bau', M. (2014). Is the family an "asset" or "liability" for firm performance? The moderating role of environmental dynamism. Journal of Small Business Management, 52(2), 210-225. https://doi.org/10.1111/jsbm.12095 
Chrisman, J. J. (2019). Stewardship theory: Realism, relevance, and family firm governance. Entrepreneurship Theory and Practice, 43(6), 1051-1066. https://doi.org/10.1177/1042258719838472

Chrisman, J. J., Chua, J. H., \& Litz, R. A. (2004). Comparing the agency costs of family and non-family firms: Conceptual issues and exploratory evidence. Entrepreneurship Theory and Practice, 28(4), 335-354. https://doi.org/10.1111/j.1540-6520.2004.00049.x

Chrisman, J. J., Chua, J. H., Pearson, A. W., \& Barnett, T. (2012). Family involvement, family influence, and familycentered non-economic goals in small firms. Entrepreneurship Theory and Practice, 36(2), 267-293. https://doi.org/10.1111/j.1540-6520.2010.00407.x

Chrisman, J. J., Chua, J. H., \& Sharma, P. (2005). Trends and directions in the development of a strategic management theory of the family firm. Entrepreneurship Theory and Practice, 29(5), 555-576. https://doi.org/10.1111/j.1540-6520.2005.00098.x

Chrisman, J. J., Memili, E., \& Misra, K. (2014). Nonfamily managers, family firms, and the winner's curse: The influence of noneconomic goals and bounded rationality. Entrepreneurship Theory and Practice, 38(5), 1103-1127. https://doi.org/10.1111/etap.12014

Corbetta, G., \& Salvato, C. (2004). Self-serving or self-actualizing? Models of man and agency costs in different types of family firms: A commentary on "Comparing the agency costs of family and non-family firms: Conceptual issues and exploratory evidence." Entrepreneurship Theory and Practice, 28(4), 355-362. https://doi.org/10.1111/j.15406520.2004.00050.x

D'Allura, G. M. (2019). The leading role of the top management team in understanding family firms: Past research and future directions. Journal of Family Business Strategy, 10(2), 87-104. https://doi.org/10.1016/j.jfbs.2018.12.001

Davis, J. H., Allen, M. R., \& Hayes, H. D. (2010). Is blood thicker than water? A study of stewardship perceptions in family business. Entrepreneurship Theory and Practice, 34(6), 1093-1116. https://doi.org/10.1111/j.15406520.2010.00415.x

Davis, J. H., Schoorman, F. D., \& Donaldson, L. (1997). Toward a stewardship theory of management. Academy of Management Review, 22(1), 20-47. https://doi.org/10.2307/259223

De Massis, A., Kotlar, J., Campopiano, G., \& Cassia, L. (2015). The impact of family involvement on SMEs' performance: Theory and evidence. Journal of Small Business Management, 53(4), 924-948. https://doi.org/10.1111/jsbm.12093

De Massis, A., Kotlar, J., Chua, J. H., \& Chrisman, J. J. (2014). Ability and willingness as sufficiency conditions for family-oriented particularistic behavior: Implications for theory and empirical studies. Journal of Small Business Management, 52(2), 344-364. https://doi.org/10.1111/jsbm.12102

Dibrell, C., \& Moeller, M. (2011). The impact of a service-dominant focus strategy and stewardship culture on organizational innovativeness in family-owned businesses. Journal of Family Business Strategy, 2(1), 43-51. https://doi.org/10.1016/j.jfbs.2011.01.004

Dillman, D. A. (2007). Mail and internet surveys: The tailored design method (2nd ed.). New York, NY: John Wiley \& Sons.

Dyer, W. G. (1989). Integrating professional management into a family owned business. Family Business Review, 2(3), 221-235. https://doi.org/10.1111/j.1741-6248.1989.00221.x

Eddleston, K. A., \& Kellermanns, F. W. (2007). Destructive and productive family relationships: A stewardship theory perspective. Journal of Business Venturing, 22(4), 545-565. https://doi.org/10.1016/j.jbusvent.2006.06.004

Eddleston, K. A., Kellermanns, F. W., \& Sarathy, R. (2007). Resource configuration in family firms: Linking resources, strategic planning and technological opportunities to performance. Journal of Management Studies, 45(1), 26-50. https://doi.org/10.1111/j.1467-6486.2007.00717.x

Eddleston, K. A., Kellermanns, F. W., \& Zellweger, T. M. (2012). Exploring the entrepreneurial behavior of family firms: Does the stewardship perspective explain differences? Entrepreneurship Theory and Practice, 36(2), 347-367. https://doi.org/10.1111/j.1540-6520.2010.00402.x

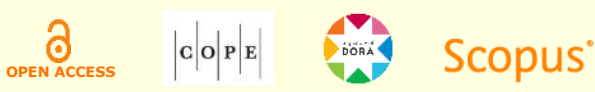


Ensley, M. D., \& Pearson, A. W. (2005). An exploratory comparison of the behavioral dynamics of top management teams in family and nonfamily new ventures: Cohesion, conflict, potency, and consensus. Entrepreneurship Theory and Practice, 29(3), 267-284. https://doi.org/10.1111/j.1540-6520.2005.00082.x

Faul, F., Erdfelder, E., Lang, A.-G., \& Buchner, A. (2007). G*Power 3: A flexible statistical power analysis program for the social, behavioral, and biomedical sciences. Behavior Research Methods, 39(2), 175-191. https://doi.org/10.3758/bf03193146

Filbeck, G., \& Lee, S. (2000). Financial management techniques in family businesses. Family Business Review, 13(3), 201-216. https://doi.org/10.1111/j.1741-6248.2000.00201.x

Finkelstein, S., \& Hambrick, D. C. (1996). Strategic leadership: Top executives and their effects on organizations. St. Paul, MN: South-Western College Pub.

Finkelstein, S., Hambrick, D. C., \& Cannella, B. (2008). Strategic leadership: Theory and research on executives, top management teams, and boards. New York, NY: Oxford University Press.

Fornell, C., \& Larcker, D. F. (1981). Structural equation models with unobservable variables and measurement error: Algebra and statistics. Journal of Marketing Research, 18(3), 382-388. https://doi.org/10.1177/002224378101800313

Frezatti, F., Bido, D. de S., Mucci, D. M., \& Beck, F. (2017). Estágios do ciclo de vida e perfil de empresas familiares brasileiras. RAE-Revista de Administração de Empresas, 57(6), 601-619. https://doi.org/10.1590/s0034759020170607

Garcia-Castro, R., \& Aguilera, R. V. (2014). Family involvement in business and financial performance: A settheoretic cross-national inquiry. Joumal of Family Business Strategy, 5(1), 85-96. https://doi.org/10.1016/j.jfbs.2014.01.006

Gomez-Mejia, L. R., Cruz, C., Berrone, P., \& De Castro, J. (2011). The bind that ties: Socioemotional wealth preservation in family firms. The Academy of Management Annals, 5(1), 653-707. https://doi.org/10.5465/19416520.2011.593320

González-Cruz, T. F., \& Cruz-Ros, S. (2016). When does family involvement produce superior performance in SME family business? Journal of Business Research, 69(4), 1452-1457. https://doi.org/10.1016/j.jbusres.2015.10.124

González, M., Guzmán, A., Pablo, E., \& Trujillo, M. A. (2020). Does gender really matter in the boardroom? Evidence from closely held family firms. Review of Managerial Science, 14(1), 221-267. https://doi.org/10.1007/s11846-018-0292-1

Gupta, V., \& Levenburg, N. (2010). A thematic analysis of cultural variations in family businesses: The CASE project. Family Business Review, 23(2), 155-169. https://doi.org/10.1177/0894486510366255

Habbershon, T. G., \& Williams, M. L. (1999). A resource-based framework for assessing the strategic advantages of family firms. Family Business Review, 12(1), 1-25. https://doi.org/10.1111/j.1741-6248.1999.00001.x

Hair, J. F., Jr., Hult, G. T. M., Ringle, C. M., \& Sarstedt, M. (2013). A primer on partial least squares structural equation modeling (PLS-SEM). Thousand Oaks, CA: Sage Publications.

Hair, J. F., Jr., Sarstedt, M., Ringle, C. M., \& Gudergan, S. P. (2017). Advanced issues in partial least squares structural equation modeling. Thousand Oaks, CA: Sage Publications.

Henssen, B., Voordeckers, W., Lambrechts, F., \& Koiranen, M. (2014). The CEO autonomy-stewardship behavior relationship in family firms: The mediating role of psychological ownership. Journal of Family Business Strategy, 5(3), 312-322. https://doi.org/10.1016/j.jfbs.2014.01.012

Hoffmann, C., Wulf, T., \& Stubner, S. (2016). Understanding the performance consequences of family involvement in the top management team: The role of long-term orientation. International Small Business Journal, 34(3), 345 368. https://doi.org/10.1177/0266242614550500

Hofstede, G. (2001). Culture's consequences: Comparing values, behaviors, institutions and organizations across nations. Thousand Oaks, CA: Sage Publications.

Instituto Brasileiro de Governança Corporativa. (2019). Governança em empresas familiares: Evidências brasileiras. Retrieved from https://www.pwc.com.br/pt/estudos/setores-atividades/pcs/2019/pesquisa-gov-emp-fam-19.pdf

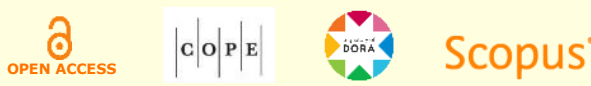


Irava, W. J., \& Moores, K. (2010). Clarifying the strategic advantage of familiness: Unbundling its dimensions and highlighting its paradoxes. Journal of Family Business Strategy, 1(3), 131-144. https://doi.org/10.1016/j.jfbs.2010.08.002

James, A. E., Jennings, J. E., \& Jennings, P. D. (2017). Is it better to govern managers via agency or stewardship? Examining asymmetries by family versus nonfamily affiliation. Family Business Review, 30(3), 262-283. https://doi.org/10.1177/0894486517717532

Jaskiewicz, P., Uhlenbruck, K., Balkin, D. B., \& Reay, T. (2013). Is nepotism good or bad? Types of nepotism and implications for knowledge management. Family Business Review, 26(2), 121-139. https://doi.org/10.1177/0894486512470841

Jensen, M. C., \& Meckling, W. H. (1976). Theory of the firm: Managerial behavior, agency costs and ownership structure. Journal of Financial Economics, 3(4), 305-360. https://doi.org/10.1016/0304-405X(76)90026-X

Kellermanns, F. W., Eddleston, K. A., \& Zellweger, T. M. (2012). Extending the socioemotional wealth perspective: A look at the dark side. Entrepreneurship Theory and Practice, 36(6), 1175-1182. https://doi.org/10.1111/j.15406520.2012.00544.x

Kim, Y., \& Gao, F. Y. (2013). Does family involvement increase business performance? Family-longevity goals' moderating role in Chinese family firms. Journal of Business Research, 66(2), 265-274. https://doi.org/10.1016/j.jbusres.2012.08.018

Lau, D. C., \& Murnighan, J. K. (1998). Demographic diversity and faultlines: The compositional dynamics of organizational groups. Academy of Management Review, 23(2), 325-340. https://doi.org/10.2307/259377

Le Breton-Miller, I., Miller, D., \& Lester, R. H. (2011). Stewardship or agency? A social embeddedness reconciliation of conduct and performance in public family businesses. Organization Science, 22(3), 704-721. https://doi.org/10.1287/orsc.1100.0541

Lubatkin, M. H., Schulze, W. S., Ling, Y., \& Dino, R. N. (2005). The effects of parental altruism on the governance of family-managed firms. Journal of Organizational Behavior, 26(3), 313-330. https://doi.org/10.1002/job.307

Madison, K., Holt, D. T., Kellermanns, F. W., \& Ranft, A. L. (2016). Viewing family firm behavior and governance through the lens of agency and stewardship theories. Family Business Review, 29(1), 65-93. https://doi.org/10.1177/0894486515594292

Madison, K., Kellermanns, F. W., \& Munyon, T. P. (2017). Coexisting agency and stewardship governance in family firms: An empirical investigation of individual-level and firm-level effects. Family Business Review, 30(4), $347-368$. https://doi.org/10.1177/0894486517727422

Martins, E., Diniz, J. A., \& Miranda, G. J. (2012). Análise avançada das demonstrações contábeis: Uma abordagem crítica. São Paulo, Brazil: Editora GEN/Atlas.

Mazzola, P., Sciascia, S., \& Kellermanns, F. W. (2013). Non-linear effects of family sources of power on performance. Journal of Business Research, 66(4), 568-574. https://doi.org/10.1016/j.jbusres.2012.01.005

Miller, D., \& Le Breton-Miller, I. (2006). Family governance and firm performance: Agency, stewardship, and capabilities. Family Business Review, 19(1), 73-87. https://doi.org/10.1111/j.1741-6248.2006.00063.x

Minichilli, A., Corbetta, G., \& MacMillan, I. C. (2010). Top management teams in family-controlled companies: "Familiness", "faultlines", and their impact on financial performance. Journal of Management Studies, 47(2), 205. 222. https://doi.org/10.1111/j.1467-6486.2009.00888.x

Neubaum, D. O., Thomas, C. H., Dibrell, C., \& Craig, J. B. (2017). Stewardship climate scale: An assessment of reliability and validity. Family Business Review, 30(1), 37-60. https://doi.org/10.1177/0894486516673701

Nitzl, C. (2016). The use of partial least squares structural equation modelling (PLS-SEM) in management accounting research: Directions for future theory development. Journal of Accounting Literature, 37, 19-35. https://doi.org/10.1016/j.acclit.2016.09.003

Nordqvist, M., Sharma, P., \& Chirico, F. (2014). Family firm heterogeneity and governance: A configuration approach. Journal of Small Business Management, 52(2), 192-209. https://doi.org/10.1111/jsbm.12096 
O'Boyle, E. H., Jr., Pollack, J. M., \& Rutherford, M. W. (2012). Exploring the relation between family involvement and firms' financial performance: A meta-analysis of main and moderator effects. Joumal of Business Venturing, 27(1), 1-18. https://doi.org/10.1016/j.jbusvent.2011.09.002

Patel, P. C., \& Cooper, D. (2014). Structural power equality between family and non-family TMT members and the performance of family firms. Academy of Management Journal, 57(6), 1624-1649. https://doi.org/10.5465/amj.2012.0681

Pearson, A. W., Carr, J. C., \& Shaw, J. C. (2008). Toward a theory of familiness: A social capital perspective. Entrepreneurship Theory and Practice, 32(6), 949-969. https://doi.org/10.1111/j.1540-6520.2008.00265.x

Peixoto, F. M., \& Buccini, A. R. A. (2013). Separação entre propriedade e controle e sua relação com desempenho e valor de empresas brasileiras: onde estamos? Revista de Contabilidade e Organizações, 7(18), 48-59. https://doi.org/10.11606/rco.v7i18.55613

Podsakoff, P. M., Mackenzie, S. B., \& Podsakoff, N. P. (2012). Sources of method bias in social science research and recommendations on how to control it. Annual Review of Psychology, 63(1), 539-569. https://doi.org/10.1146/annurev-psych-120710-100452

Purkayastha, S., Veliyath, R., \& George, R. (2019). The roles of family ownership and family management in the governance of agency conflicts. Journal of Business Research, 98, 50-64. https://doi.org/10.1016/j.jbusres.2019.01.024

Rutherford, M. W., Kuratko, D. F., \& Holt, D. T. (2008). Examining the link between "familiness" and performance: Can the F-PEC untangle the family business theory jungle? Entrepreneurship Theory and Practice, 32(6), 1089-1109. https://doi.org/10.1111/j.1540-6520.2008.00275.x

Sarstedt, M., Ringle, C. M., Smith, D., Reams, R., \& Hair, J. F. (2014). Partial least squares structural equation modeling (PLS-SEM): A useful tool for family business researchers. Journal of Family Business Strategy, 5(1), 105115. https://doi.org/10.1016/j.jfbs.2014.01.002

Schulze, W. S., Lubatkin, M. H., \& Dino, R. N. (2003). Exploring the agency consequences of ownership dispersion among the directors of private family firms. Academy of Management Journal, 46(2), 179-194. https://doi.org/10.5465/30040613

Sciascia, S., \& Mazzola, P. (2008). Family involvement in ownership and management: Exploring nonlinear effects on performance. Family Business Review, 21(4), 331-345. https://doi.org/10.1177/08944865080210040105

Sciascia, S., Mazzola, P., \& Chirico, F. (2013). Generational involvement in the top management team of family firms: Exploring nonlinear effects on entrepreneurial orientation. Entrepreneurship: Theory and Practice, 37(1), 69. 85. https://doi.org/10.1111/j.1540-6520.2012.00528.x

Speckbacher, G., \& Wentges, P. (2012). The impact of family control on the use of performance measures in strategic target setting and incentive compensation: A research note. Management Accounting Research, 23(1), 34-46. https://doi.org/10.1016/j.mar.2011.06.002

Vandekerkhof, P., Steijvers, T., Hendriks, W., \& Voordeckers, W. (2015). The effect of organizational characteristics on the appointment of nonfamily managers in private family firms. Family Business Review, 28(2), 104-122. https://doi.org/10.1177/0894486513514274

Verbeke, A., \& Kano, L. (2012). The transaction cost economics theory of the family firm: Family-based human asset specificity and the bifurcation bias. Entrepreneurship Theory and Practice, 36(6), 1183-1205. https://doi.org/10.1111/j.1540-6520.2012.00545.x

Villalonga, B., \& Amit, R. (2006). How do family ownership, control and management affect firm value? Journal of Financial Economics, 80(2), 385-417. https://doi.org/10.1016/j.jfineco.2004.12.005

Wagner, D., Block, J. H., Miller, D., Schwens, C., \& Xi, G. (2015). A meta-analysis of the financial performance of family firms: Another attempt. Journal of Family Business Strategy, 6(1), 3-13. https://doi.org/10.1016/j.jfbs.2015.01.001

Zahra, S. A., Hayton, J. C., Neubaum, D. O., Dibrell, C., \& Craig, J. (2008). Culture of family commitment and strategic flexibility: The moderating effect of stewardship. Entrepreneurship Theory and Practice, 32(6), 1035-1054. https://doi.org/10.1111/j.1540-6520.2008.00271.x

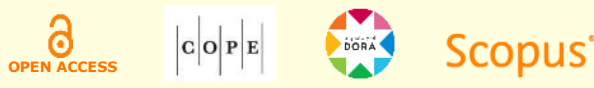




\section{Author contributions}

$1^{\text {st }}$ author: conceptualization (lead), data curation (lead), formal analysis (equal), investigation (equal), methodology (equal), project administration (lead), writing-original draft (lead), writing-review and editing (equal).

$2^{\text {nd }}$ author: conceptualization (equal), investigation (equal), project administration (equal), supervision (equal), writing-original draft (equal), writing-review and editing (equal).

$3^{\text {rd }}$ author: conceptualization (equal), investigation (equal), project administration (equal), supervision (equal), writing-original draft (equal), writing-review and editing (equal).

$4^{\text {th }}$ author: formal analysis (equal), methodology (equal), writing-review and editing (equal).

\section{Authors}

\section{Daniel Magalhães Mucci}

Universidade de São Paulo, Faculdade de Economia, Administração, Contabilidade e Atuária

Av. Prof. Luciano Gualberto, 908, FEA 3, sala 234, Butantã, Cidade Universitária, 05508-010, São Paulo, SP, Brazil danielmmucci@usp.br

(iD) https://orcid.org/0000-0002-0658-1470

\section{Fábio Frezatti}

Universidade de São Paulo, Faculdade de Economia, Administração, Contabilidade e Atuária Av. Prof. Luciano Gualberto, 908, Butantã, Cidade Universitária, 05508-010, São Paulo, SP, Brazil frezatti@usp.br

(iD) https://orcid.org/0000-0002-5927-022X

\section{Ann Jorissen}

Universiteit Antwerpen, Accountancy and Finance

Stadscampus, B-building, S.B.329, Prinsstraat 13, 2000 Antwerp, Belgium

ann.jorissen@uantwerpen.be

(iD) https://orcid.org/0000-0001-5213-0526

\section{Diógenes de Souza Bido}

Universidade Presbiteriana Mackenzie, Programa de Pós-graduação em Administração

Rua da Consolação, 930, 01302-907, São Paulo, SP, Brazil

diogenesbido@yahoo.com.br

(iD) https://orcid.org/0000-0002-8525-5218

Peer review is responsible for acknowledging an article's potential contribution to the frontiers of scholarly knowledge on business or public administration. The authors are the ultimate responsible for the consistency of the theoretical references, the accurate report of empirical data, the personal perspectives, and the use of copyrighted material. 


\section{APPENDIX}

Additional analysis

\section{Structural model - ROS dependent variable}

\begin{tabular}{|c|c|c|c|c|c|c|c|}
\hline $\begin{array}{l}\text { Dependent variable: ROS } \\
\text { Path coefficients } \\
n=64\end{array}$ & Model 1 & Model 2 & Model 3 & Model 4 & Model 5 & Model 6 & Model 7 \\
\hline \multicolumn{8}{|l|}{ Controls } \\
\hline Firm size & 0.061 & 0.001 & 0.004 & 0.021 & -0.007 & 0.003 & 0.016 \\
\hline Firm age & 0.022 & -0.028 & -0.020 & -0.038 & -0.093 & -0.085 & -0.070 \\
\hline Ownership & 0.123 & 0.194 & 0.179 & 0.168 & 0.175 & 0.144 & 0.150 \\
\hline \multicolumn{8}{|l|}{ Independent variables } \\
\hline Family CEO & 0.224 & $0.359^{* *}$ & $0.394^{* *}$ & $0.427^{* *}$ & $0.363^{*}$ & $0.435^{\star *}$ & $0.495^{\star *}$ \\
\hline TMT Family Ratio & & $-0.384^{* * *}$ & $-0.468^{* *}$ & $-0.540^{* * *}$ & $-0.409^{* * *}$ & $-0.581^{* * *}$ & $-0.615^{\star * *}$ \\
\hline TMT Family Ratio ${ }^{2}$ & & & 0.132 & $0.245^{\star}$ & & $0.269^{*}$ & $0.293^{\star \star}$ \\
\hline Stewardship & & & & -0.318 & -0.237 & -0.329 & -0.336 \\
\hline \multicolumn{8}{|l|}{ Interactions Stewardship } \\
\hline Family CEO * Stewardship & & & & & $-0.363^{* *}$ & $-0.380^{* * *}$ & $-0.451^{* * *}$ \\
\hline TMT Family Ratio * Stewardship & & & & 0.001 & & & 0.200 \\
\hline $\mathrm{R} 2$ & 0.058 & 0.169 & 0.185 & 0.273 & 0.338 & 0.398 & 0.422 \\
\hline Adj R2 & 0.000 & 0.097 & 0.099 & 0.168 & 0.255 & 0.311 & 0.325 \\
\hline
\end{tabular}

Note. † 0.10-level. * 0.05 -level. ${ }^{* *} 0.01$-level. ${ }^{* * *} 0.001$-level.

Structural model - ROA dependent variable

\begin{tabular}{|c|c|c|c|c|c|c|c|}
\hline $\begin{array}{l}\text { Dependent variable: } R O A \\
\text { Path coefficients } \\
n=64\end{array}$ & Model 1 & Model 2 & Model 3 & Model 4 & Model 5 & Model 6 & Model 7 \\
\hline \multicolumn{8}{|l|}{ Controls } \\
\hline Firm size & 0.014 & -0.015 & -0.012 & 0.005 & -0.017 & -0.007 & -0.007 \\
\hline Firm age & 0.149 & 0.126 & 0.132 & 0.063 & 0.022 & 0.022 & 0.023 \\
\hline Ownership & $0.224^{* *}$ & $0.257^{\star *}$ & $0.246^{* *}$ & $0.248^{*}$ & $0.237^{*}$ & $0.214^{*}$ & $0.213^{*}$ \\
\hline \multicolumn{8}{|l|}{ Independent variables } \\
\hline Family CEO & 0.134 & 0.196 & 0.223 & 0.257 & 0.241 & $0.317^{*}$ & $0.321 \dagger$ \\
\hline TMT Family Ratio & & -0.178 & -0.242 & $-0.334^{*}$ & $-0.241 \dagger$ & $-0.402^{* *}$ & $-0.404^{* *}$ \\
\hline TMT Family Ratio² & & & 0.100 & 0.199 & & $0.236^{*}$ & $0.237^{*}$ \\
\hline Stewardship & & & & -0.309 & -0.253 & -0.332 & -0.333 \\
\hline \multicolumn{8}{|l|}{ Interactions Stewardship } \\
\hline Family CEO * Stewardship & & & & & $-0.391^{* *}$ & $-0.409^{* * *}$ & $-0.414^{* *}$ \\
\hline TMT Family Ratio * Stewardship & & & & -0.180 & & & 0.014 \\
\hline $\mathrm{R} 2$ & 0.080 & 0.103 & 0.113 & 0.218 & 0.295 & 0.342 & 0.342 \\
\hline Adj R2 & 0.017 & 0.026 & 0.020 & 0.105 & 0.206 & 0.246 & 0.232 \\
\hline
\end{tabular}

Note. † 0.10-level. ${ }^{*} 0.05$-level. ${ }^{* *} 0.01$-level. ${ }^{* * *} 0.001$-level. 